\title{
Persistent changes in spinal cord gene expression after recovery from inflammatory hyperalgesia: A preliminary study on pain memory \\ Rustam Yukhananov*1,3 and Igor Kissin ${ }^{2,3}$
}

Address: ${ }^{1}$ Neurogenomic Laboratory Department of Anesthesiology, Perioperative and Pain Medicine, Brigham and Women's Hospital, Boston, MA 02115, USA, ${ }^{2}$ Behavioral Laboratory, Pain Research Center, Department of Anesthesiology, Perioperative and Pain Medicine, Brigham and Women's Hospital, Boston, MA 02115, USA and ${ }^{3}$ Harvard Medical School, Boston, MA 02115, USA

Email: Rustam Yukhananov* - ryyukhan@zeus.bwh.harvard.edu; Igor Kissin - kissin@zeus.bwh.harvard.edu

* Corresponding author

Published: I 3 March 2008

BMC Neuroscience 2008, 9:32 doi:10.1 |86/147|-2202-9-32
Received: 6 August 2007

Accepted: 13 March 2008

This article is available from: http://www.biomedcentral.com/147I-2202/9/32

(c) 2008 Yukhananov and Kissin; licensee BioMed Central Ltd.

This is an Open Access article distributed under the terms of the Creative Commons Attribution License (http://creativecommons.org/licenses/by/2.0), which permits unrestricted use, distribution, and reproduction in any medium, provided the original work is properly cited.

\begin{abstract}
Background: Previous studies found that rats subjected to carrageenan injection develop hyperalgesia, and despite complete recovery in several days, they continue to have an enhanced hyperalgesic response to a new noxious challenge for more than $28 \mathrm{~d}$. The study's aim was to identify candidate genes that have a role in the formation of the long-term hyperalgesia-related imprint in the spinal cord. This objective was undertaken with the understanding that the longlasting imprint of acute pain in the central nervous system may contribute to the transition of acute pain to chronicity.
\end{abstract}

Results: To analyze changes in gene expression when carrageenan-induced hyperalgesia has disappeared but propensity for the enhanced hyperalgesic response is still present, we determined the gene expression profile using oligo microarray in the lumbar part of the spinal cord in three groups of rats: $28 \mathrm{~d}$ after carrageenan injection, $24 \mathrm{~h}$ after injection (the peak of inflammation), and with no injection (control group). Out of 17,000 annotated genes, 356 were found to be differentially expressed compared with the control group at $28 \mathrm{~d}$, and 329 at $24 \mathrm{~h}$ after carrageenan injection (both groups at $p<0.01$ ). Among differentially expressed genes, 67 (39 in 28d group) were identified as being part of pain-related pathways, altered in different models of pain, or interacting with proteins involved in pain-related pathways. Using gene ontology (GO) classification, we have identified 3 functional classes deserving attention for possible association with pain memory: They are related to cell-to-cell interaction, synaptogenesis, and neurogenesis.

Conclusion: Despite recovery from inflammatory hyperalgesia, persistent changes in spinal cord gene expression may underlie the propensity for the enhanced hyperalgesic response. We suggest that lasting changes in expression of genes involved in the formation of new synapses and neurogenesis may contribute to the transition of acute pain to chronicity.

\section{Background}

Pain that persists well beyond the healing of the injury, including surgical wounds, is a major clinical problem [1]. Multiple mechanisms are likely responsible for per- 
sistent postinjury pain; some may be related to the transition of acute pain to chronicity, a concept that is supported by reports of the relationship between the intensity of acute postoperative pain and subsequent development of chronic pain after surgery [2-4]. A longlasting imprint of acute pain may contribute to its transition to chronic pain. In the rat model, acute pain and hyperalgesia following an inflammation disappeared within a few days, but enhanced sensitivity to a new noxious challenge (inflammation) may persist for a very long time $[5,6]$. Our previous experiments with repeated injections of carrageenan into the hindpaws demonstrated that, well after recovery ( 2 to 4 weeks later) from hyperalgesia induced by the initial inflammation, repeated-crossover carrageenan injection causes a distant (in contralateral hindpaw) hyperalgesia that was absent after the initial injection. The acute pain and hyperalgesia following an injection of carrageenan disappears within a few days, but despite recovery the enhanced response to a new noxious challenge may persist for a very long time $[5,7]$. This phenomenon was viewed as an indication of the long-lasting imprint of acute pain in the CNS [7].

It seems plausible that the transition to chronic pain involved modification of gene expression within the spinal cord, which might be a mechanism of long-term imprinting of pain hypersensitivity. However, the picture of gene expression alterations and their role in control of acute and chronic pain is far from clear [8-10]. Multiple pathways seems to be involved, and their elucidation will require global profile studies of gene expression using different models of acute and chronic pain with and without drug intervention. We have found no studies on changes in gene expression long after recovery from inflammatory hyperalgesia. The aim of this study was to characterize changes in gene expression when animals are long recovered from hyperalgesia but have maintained a propensity for enhanced hyperalgesic response. We hypothesized that following the recovery from inflammatory hyperalgesia there were persistent changes in spinal cord gene expression.

\section{Results}

Carrageenan injection into a rat's hind paw induces inflammation and hyperalgesia (Fig. 1). Inflammation measured as increased paw volume reaches its maximum $3-24 \mathrm{~h}$ after injection. The differences in paw volume between the injected and contralateral paws are minimal after 5 days and completely disappear in 2 weeks (Fig. 1B). Injection-induced hyperalgesia disappears at 24h (Fig. 1A). However, as was shown in previous experiments, after recovery from hyperalgesia a repeated-crossover injection of carrageenan (in the opposite hindpaw) produced a more exaggerated response, resulting in profound distant hyperalgesia in the originally injected paw even 28d later [7]. In order to distinguish the acute changes
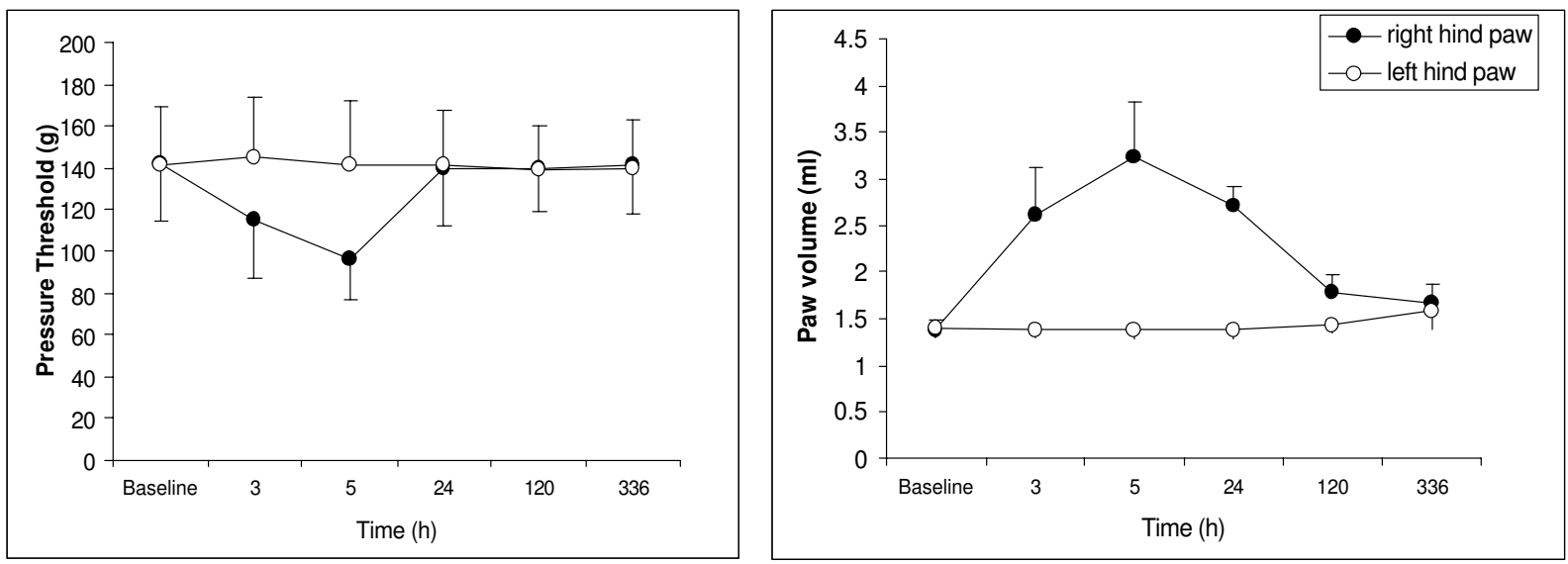

\section{Figure I}

Effect of carrageenan on noxious pressure threshold and paw volume. The carrageenan was injected in the plantar surface of the right paw $(2 \%, 0.1 \mathrm{ml})$. Left Graph. Noxious pressure threshold was measured by Analgesia-Meter (Ugo Basile). Right Graph. Volume measured by a plethysmometer. Data expressed as mean \pm SD. The threshold to noxious pressure in the right hindpaw, decreased after carrageenan injection, recovered the next day and was equal to the threshold in the left hindpaw for the whole period of observation (up to 28d). 
induced by inflammation from long-term changes related to pain memory, we collected tissue samples both at $24 \mathrm{~h}$ following injection, when the inflammation is still significant but there is no hyperalgesia, and at $28 \mathrm{~d}$, when as reported previously [7] there is no inflammation but enhanced response to pain stimulus, or "pain memory."

The statistical analysis of gene expression data is still a challenge. There is no standard approach to select differentially expressed genes. Often the combination of p-values and fold differences is used to select "interesting" genes for further analysis [10]. However, to use fold changes for the central nervous system is not efficient, since the changes in gene expression are small and diluted by the large variety of unaffected neurons. In addition, fold changes are not statistically validated metrics and in many cases produce spurious results [11]. In this study, we used the Rosetta Resolver statistical model and based our analysis only on p-value. We compared the number of differentially expressed genes at different p-values. For further analysis, we have used $\mathrm{p}<0.01$ as a cutoff. It was shown that selecting genes based on $\mathrm{p}<0.01$ results in more than $80 \%$ confirmation rate by real-time PCR [12] and provides a reasonable compromise between stringency and exploratory value of the analysis (Table 1). Using this method we have identified 629 differentially expressed genes in the $28 \mathrm{~d}$ group and 512 genes in the $24 \mathrm{~h}$ group out of a total of 31,042 reliably measured transcripts (see Additional file 1). These numbers include both annotated and uncharacterized genes (EST). Further analysis was limited to 356 full-length annotated genes that were differentially expressed compared with the control group at $28 \mathrm{~d}$ after injection and 329 full-length annotated genes that were differentially expressed compared with the control group at $24 \mathrm{~h}$ after injection (see Additional file 1). The low variability of our data permitted us to detect highly significant differences with relative changes as low as $10 \%$.

In the next step we have characterized the functional groups based on gene ontology (GO) classification using DAVID tools (Table 2 and 3). There are several groups overrepresented only at $24 \mathrm{~h}$, when inflammatory response is near its peak (Table 2): protein synthesis/ ribosomal protein group and proteins involved in the

Table I: The number of probe set selected according to p-value.

\begin{tabular}{lcc}
\hline p-value & 28d vs control & 24h vs control \\
\hline All & 31042 & 31042 \\
$<0.05$ & 1781 & 1560 \\
$<0.01$ & 629 & 512 \\
$<0.005$ & 441 & 358 \\
$<0.001$ & 177 & 167
\end{tabular}

immune response. Chaperones involved in protein folding were also overrepresented at $24 \mathrm{~h}$ but with smaller probability. The different groups were overrepresented at 28d (Table 3), such as the genes involved in cell-to-cell interaction, cell proliferation and neurogenesis, morphogenesis, and neuron differentiation-in other words, involved in the formation of new synapses and neurogenesis. DAVID-based GO analysis showed that genes responsible for regulation of apoptosis, phosphorylation, and acetylation were also overrepresented only at $28 \mathrm{~d}$ group (Table 3). Several functional groups related to regulatory pathways were overrepresented both at $24 \mathrm{~h}$ and $28 \mathrm{~d}$, for example, proteins responsible for ion binding (Table 2 and 3) but it may reflect their overrepresentation in neurons since we have used Affy chip as background for analysis (see Methods). Using SOM, we have grouped the known differentially expressed genes into eight clusters (Fig. 2). Clusters A and B contain the majority of selected genes $(n=233)$. Cluster $A(n=122)$ includes genes that increased at $24 \mathrm{~h}$ after injection and then increased even further at 28d, whereas genes belonging to cluster B ( $\mathrm{n}=$ $111)$ changed in the opposite direction: They decreased at $24 \mathrm{~h}$ and further decreased at $28 \mathrm{~d}$. Clusters C and D are similar and include 51 genes that are practically not altered $24 \mathrm{~h}$ after injection but then slightly increased (cluster C) or slightly decreased (cluster D) at 28d. Genes $(\mathrm{n}=177)$ belonging to clusters $\mathrm{E}$ and $\mathrm{H}$ increased at $24 \mathrm{~h}$ (cluster E) or decreased (cluster $\mathrm{H}$ ) and remained at the same level up to $28 \mathrm{~d}$ after injection. The last two clusters ( $\mathrm{G}$ and $\mathrm{F}$ ) include genes that increased $(\mathrm{F})$ or decreased (G) at $24 \mathrm{~h}$ and returned to the control level at $28 \mathrm{~d}$.

In order to see whether clusters $\mathrm{G}$ and $\mathrm{F}$ reflect changes in gene expression related to ongoing inflammation, we have selected the group $(\mathrm{n}=16)$ of known mediators of inflammation. They have a similar profile with maximal changes at $24 \mathrm{~h}$ following injection and practically expressed at the same level as the control group $28 \mathrm{~d}$ following injection (Fig. 3).

As indirect validation of our result, among differentially expressed genes in both groups we identified (see methods) 67 genes ( 39 in the $28 \mathrm{~d}$ group) previously reported to be involved in pain-related pathways, altered in different models of pain, or interacting with protein involved in pain. These genes were divided into several functional groups (Table 4). The first group includes membrane receptors and their ligands. The second contains ion channels, regulators of ion homeostasis, and calcium sensors (e.g., calmodulin) (Table 3). We selected 2 groups that contain signal transduction molecules: the MAPK pathway and proteins involved in cAMP signaling. The fifth group consists of growth factors known to modify pain sensitivity: BDNF [13] and its receptor (NtrkB), neuregulin1, and IGF binding proteins. The sixth group 
Table 2: Ontologic classification of genes differentially expressed at $24 \mathrm{~h}$ and $28 \mathrm{~d}(\mathrm{~B})$.

\begin{tabular}{|c|c|c|c|}
\hline Category & Number of sequences & $\%$ of total & $\mathrm{p}$-value \\
\hline \multicolumn{4}{|l|}{ Protein synthesis/ribosome } \\
\hline ribosome & 18 & $5.20 \%$ & $6.10 \mathrm{E}-12$ \\
\hline protein biosynthesis & 19 & $5.50 \%$ & $3.60 \mathrm{E}-10$ \\
\hline ribonucleoprotein complex & 25 & $7.30 \%$ & I.80E-08 \\
\hline eukaryotic $43 S$ preinitiation complex & 7 & $2.00 \%$ & I.60E-05 \\
\hline eukaryotic $48 \mathrm{~S}$ initiation complex & 6 & $1.70 \%$ & $6.00 \mathrm{E}-05$ \\
\hline \multicolumn{4}{|l|}{ Protein folding } \\
\hline posttranslational protein folding & 4 & $1.20 \%$ & $2.40 \mathrm{E}-03$ \\
\hline chaperone cofactor dependent protein folding & 4 & $1.20 \%$ & I.40E-03 \\
\hline response to unfolded protein & 6 & $1.70 \%$ & 2.70E-03 \\
\hline \multicolumn{4}{|l|}{ Immune response } \\
\hline immunoglobulin domain & 16 & $4.70 \%$ & 4.90E-05 \\
\hline A-macroglobulin receptor & 3 & $0.90 \%$ & $1.20 \mathrm{E}-02$ \\
\hline \multicolumn{4}{|l|}{ Regulatory pathway } \\
\hline response to stress & 34 & $9.90 \%$ & $5.50 E-03$ \\
\hline signal transduction inhibitor & 4 & $1.20 \%$ & $6.90 \mathrm{E}-03$ \\
\hline cation binding & 44 & $12.80 \%$ & $3.60 \mathrm{E}-03$ \\
\hline calmodulin binding & 6 & $1.70 \%$ & 7.50E-03 \\
\hline
\end{tabular}

Functional analysis of differentially expressed transcript employed DAVID tools (see Methods for detailed description). To calculate background, Affychip has been used. Some transcripts represent in more than one category. Cutoff value for category selection $\mathrm{p}<0.05$.

includes critical components of the arachidonic acid (AA) cascade, a known mediator of inflammatory pain.

Several genes ("Others", group 7) did not fit in any of these groups. Gene expression of this group (Table 4) has been reported to be altered in different pain models. Annexin 3 level was increased during episodes of migraine
[14]; microtubule-associated protein $1 \mathrm{~B}$ was altered 7 days after chronic constriction injury (CCI) [15]; synaptoporin, a major synaptic vesicle protein in Adelta- and Cfibers and co-localized with calcitonin gene-related peptide (CGRP) in sensory primary afferent neurons, increased after peripheral nerve injury [16].

Table 3: Ontologic classification of genes differentially expressed at 28d.

\begin{tabular}{|c|c|c|c|}
\hline Category & Number of sequences & $\%$ of total & $\mathrm{p}$-value \\
\hline Cadherin-like & 13 & $3.40 \%$ & I.30E-I4 \\
\hline cell-cell adhesion & 18 & $4.70 \%$ & 4. $10 \mathrm{E}-07$ \\
\hline \multicolumn{4}{|l|}{ Synapse formation } \\
\hline regulation of cell proliferation & 20 & $5.20 \%$ & $5.70 \mathrm{E}-04$ \\
\hline neurogenesis & 15 & $3.90 \%$ & $7.60 \mathrm{E}-03$ \\
\hline morphogenesis & 34 & $8.90 \%$ & $2.70 \mathrm{E}-03$ \\
\hline neuron differentiation & 15 & $3.90 \%$ & $2.80 \mathrm{E}-03$ \\
\hline \multicolumn{4}{|l|}{ Apoptosis } \\
\hline regulation of apoptosis & 22 & $5.80 \%$ & I.80E-04 \\
\hline negative regulation of apoptosis & 12 & $3.10 \%$ & 8.90E-04 \\
\hline \multicolumn{4}{|l|}{ Regulatory pathways } \\
\hline calcium ion binding & 31 & $8.10 \%$ & $2.60 \mathrm{E}-06$ \\
\hline ion binding & 62 & $16.30 \%$ & $5.50 \mathrm{E}-04$ \\
\hline transmission of nerve impulse & 20 & $5.20 \%$ & 4.90E-04 \\
\hline actin polymerization and/or depolymerization & 7 & $1.80 \%$ & $2.40 \mathrm{E}-04$ \\
\hline cytoskeleton organization and biogenesis & 18 & $4.70 \%$ & I.70E-03 \\
\hline nerve ensheathment & 5 & $1.30 \%$ & 4.30E-03 \\
\hline \multicolumn{4}{|l|}{ Enzyme } \\
\hline phosphorylation & 39 & $10.20 \%$ & $9.50 \mathrm{E}-04$ \\
\hline acetylation & 14 & $3.70 \%$ & $3.20 \mathrm{E}-03$ \\
\hline
\end{tabular}

Functional analysis of differentially expressed transcript employed DAVID tools (see Methods for detailed description). To calculate background, Affychip has been used. Some transcripts represent in more than one category. Cutoff value for category selection $p<0.05$. 

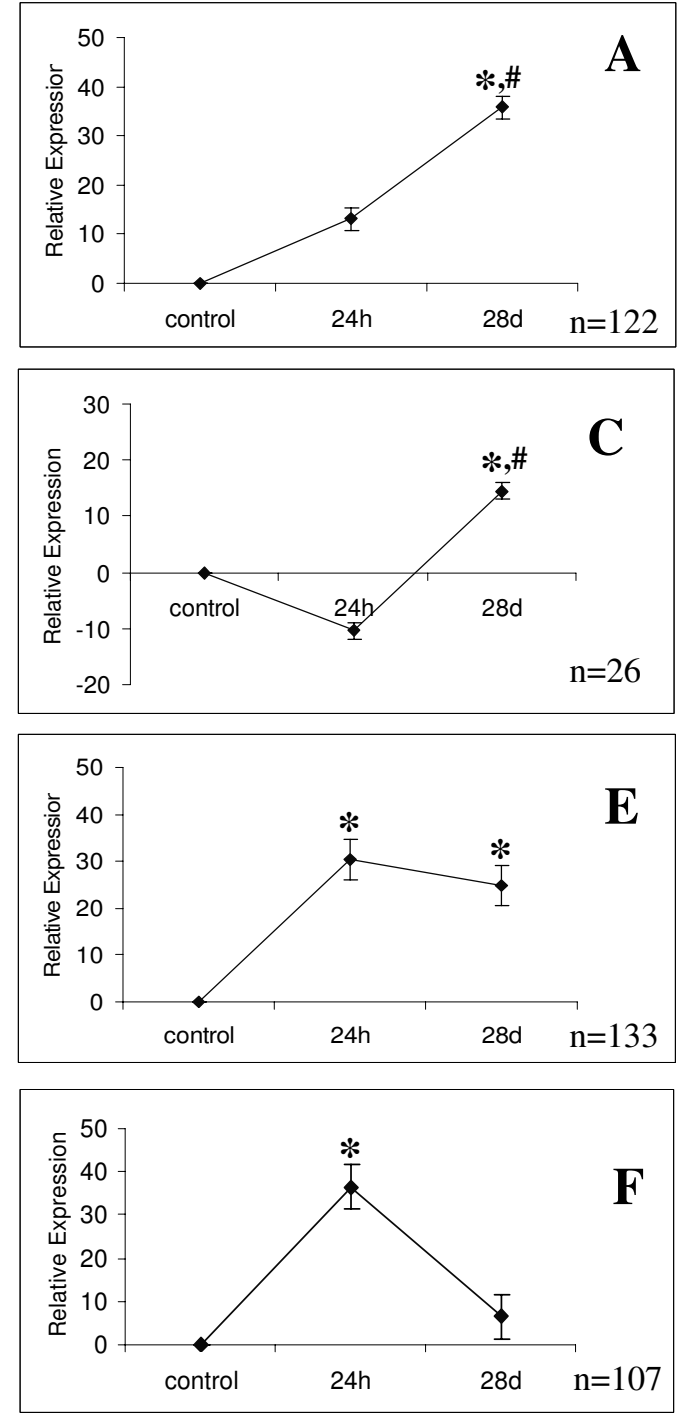
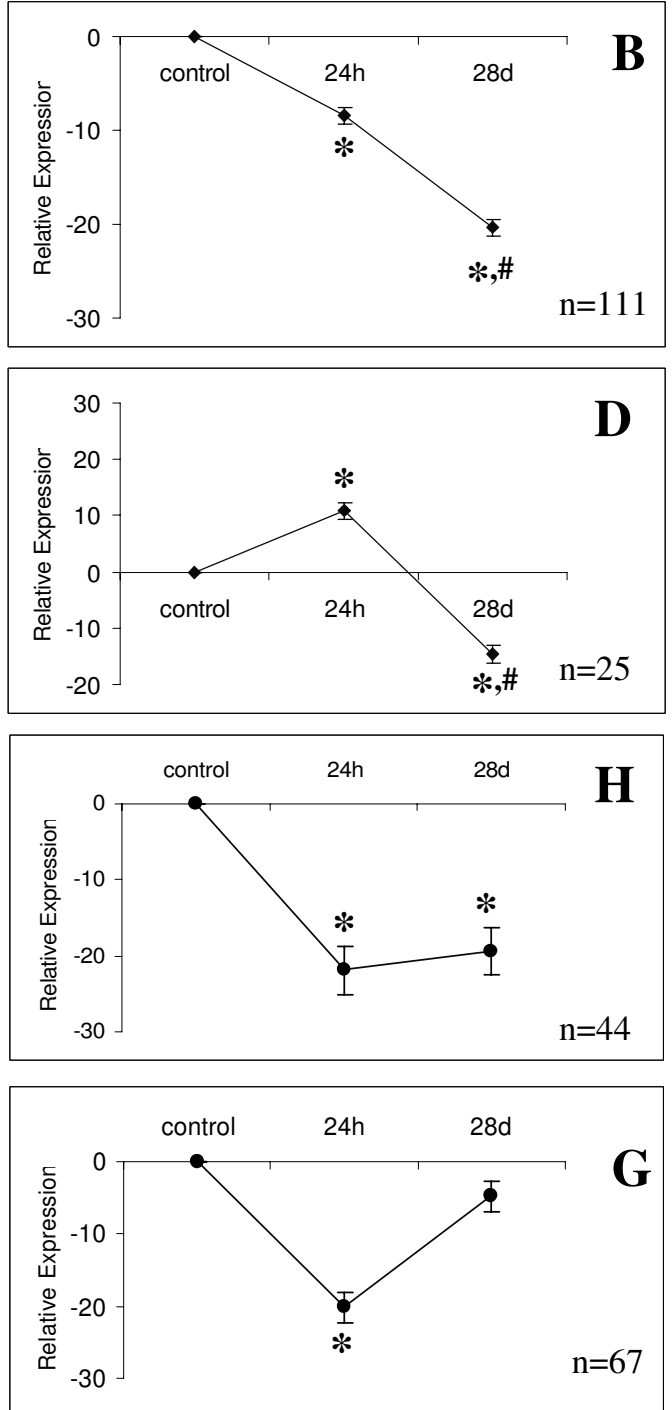

\section{Figure 2}

Clustering of genes differentially expressed at $\mathbf{2 4 h}$ and $\mathbf{2 8 d}$. Data presented as mean \pm SEM. Genes were classified by SOM; $n=$ number of genes in each cluster. ${ }^{*}-p<0.00$ I compared to control, \#- $p<0.00$ l compared to $24 \mathrm{~h}$ group.

Several genes were included in group 7 based on indirect evidence of their involvement in pain regulation. Tubulin isoform beta5 interacts with vanilloid receptor (TRPV1) and is probably a downstream effector of TRPV1 activation [17]. Chaperonin subunit 4 (cct4) involved in folding tubulin and other cytosolic proteins is included, since mutation of this protein leads to early onset sensory neuropathy [18]. Fyn proto-oncogene phosphorylates NMDA receptors in response to pain stimuli [19].
In order to verify the microarray result by independent methods, we randomly selected six of the differentially expressed genes and two non-differentially expressed genes to measure their expression by qPCR (Fig. 4). We found significant $(p<0.001)$ correlation between expression value obtained using microarray and the real-time PCR results at $28 \mathrm{~d}$ following carrageenan injection. 


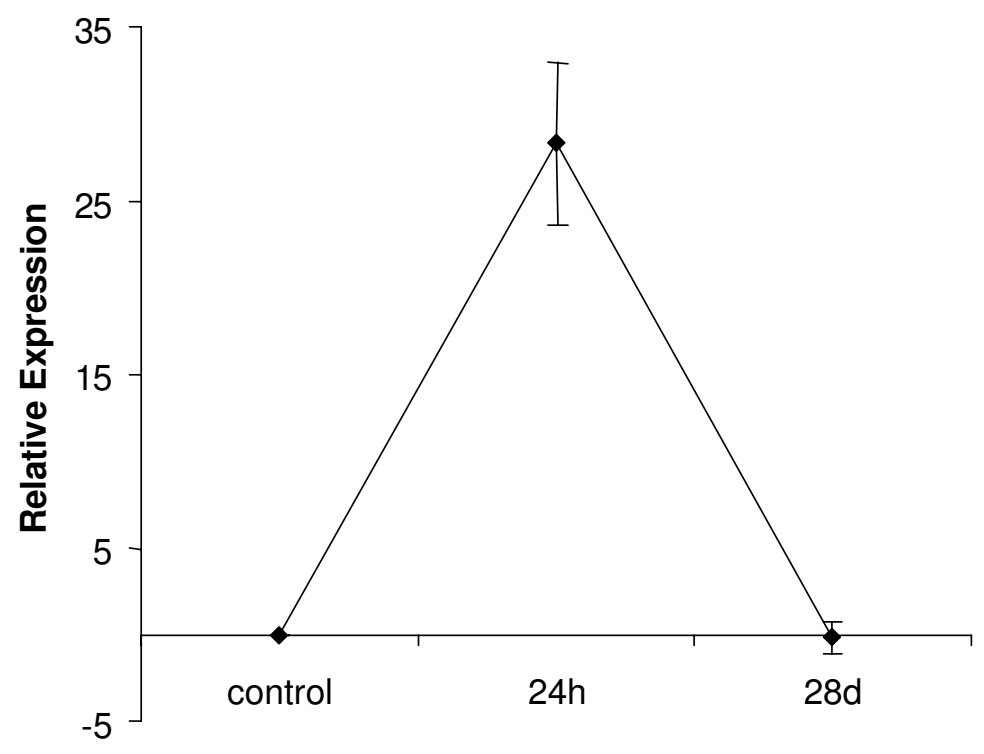

\begin{tabular}{|l|l|l|l|}
\hline Name & Affymetrix & GenBank & Description \\
\hline Cxcl9 & 1373544_at & NM_145672 & chemokine ligand 9 \\
\hline Csf1r & 1388784_at & NM_001029901 & Macrophage colony stimulating factor I receptor \\
\hline II10 & 1387711_at & NM_012854 & interleukin 10 \\
\hline II2rb & 1387394_at & NM_013195 & interleukin 2 receptor beta chain \\
\hline II6ra & 1386987_at & NM_017020 & interleukin 6 receptor, alpha \\
\hline II13ra1 & 1388711_at & NM_145789 & interleukin 13 receptor, alpha 1 \\
\hline II1r2 & 1387180_at & NM_053953 & interleukin 1 receptor type II \\
\hline Tnfrsf4 & 1387621_at & NM_013049 & tumor necrosis factor receptor superfamily member 4 \\
\hline Tnfrsf1a & 1367715_at & NM_013091 & tumor necrosis factor receptor superfamily, member 1a \\
\hline II18 & 1369665_a_at & NM_019165 & interleukin 18 \\
\hline Litaf & 1370928_at & BI284739 & LPS-induced TNF-alpha factor \\
\hline II6st & 1383489_at & NM_001008725 & interleukin 6 signal transducer \\
\hline Ccl17 & 1370118_at & NM_057151 & small inducible cytokine subfamily A (Cys-Cys) member 17 \\
\hline Tnfsf13 & 1377353_a_at & NM_001009623 & TNF superfamily member 13 \\
\hline Ccl7 & 1379935_at & NM_001007612 & chemokine ligand 7 \\
\hline II24 & 1368210_at & NM_133311 & interleukin 24 \\
\hline
\end{tabular}

Figure 3

Profile of gene expression for inflammation-related genes. The selected inflammation-related genes were clustered with SOM. Data presented as mean \pm SEM.

\section{Discussion}

The acute pain following a single injection of carrageenan disappears within a few days; however, the enhanced sensitivity to a new noxious challenge may persist for a prolonged time [5-7]. The enhanced sensitivity may contribute to posttraumatic and postsurgical persistent pain. In experiments with repeated carrageenan injections in response to the first injection into a rat's hind paw, the induced hyperalgesia was profound on the side of injection and minimal or absent in the contralateral hind paw. However, repeated injection of carrageenan into the previously noninjected hind paw resulted in pronounced hyperalgesia in the other paw. The difference between distant hyperalgesia after the initial and repeated-crossover injection of carrageenan was used as a measure of the 
Table 4: Genes differentially expressed $24 \mathrm{~h}$ or $28 \mathrm{~d}$ following carrageenan injection and known to be involved in pain.

\begin{tabular}{|c|c|c|c|c|c|c|}
\hline GenBank & Description & Name & P-value & Cluster & Selection criteria & References \\
\hline & I. Membrane receptors and their ligands & & & & & \\
\hline NM 022225 & 5-hydroxytryptamine (serotonin) receptor Ib & $\mathrm{Htrlb}$ & 0.0005 & $A$ & w & {$[48] ;[49]$} \\
\hline NM 012685 & vasoactive intestinal peptide receptor I & Vipr I & 0.0017 & A & w & {$[50]$} \\
\hline$\underline{\text { U30290 }}$ & galanin receptor I & Galr I & 0.0095 & B & w & {$[51]$} \\
\hline$\overline{\mathrm{B} 1395810}$ & neuropeptide y receptor yl & Npylr & 0.0085 & B & w & [52] \\
\hline NM 017155 & adenosine al receptor & Adoral & 0.0034 & $\mathrm{E}$ & w & [53] \\
\hline U28430 & 5-hydroxytryptamine (serotonin) receptor 3a & Htr3a & 0.0002 & $\mathrm{E}$ & w & [48] \\
\hline NM 022695 & neurotensin receptor 2 & Ntsr2 & 0.0001 & $\mathrm{E}$ & w & [54] \\
\hline BF4|273| & prodynorphin & Pdyn & 0.0000 & $\mathrm{~F}$ & $w, z$ & [55] \\
\hline MII596 & calcitonin-related polypeptide, beta & Calcb & 0.0000 & G & $w, z$ & [56] \\
\hline$\overline{\mathrm{BG} 376217}$ & glutamate receptor, ionotropic, ampal (alpha I) & Grial & 0.0073 & $\mathrm{H}$ & w & [57] \\
\hline NM 017011 & glutamate receptor, metabotropic I & Grml & 0.0000 & $\mathrm{H}$ & w & [37] \\
\hline NM 012870 & neuropeptide y receptor y 5 & Npy5r & 0.0021 & $\mathrm{H}$ & $w, z$ & [32]; [58] \\
\hline
\end{tabular}

2. Ion channels and regulator of ion homeostasis

\begin{tabular}{|c|c|c|c|c|c|c|}
\hline Al010839 & $\begin{array}{l}\text { potassium large conductance calcium-activated channel, } \\
\text { subfamily m, alpha member I }\end{array}$ & Kenmal & 0.0050 & A & w & [59] \\
\hline M34052 & $\begin{array}{l}\text { potassium voltage gated channel, shaw-related subfamily, } \\
\text { member } 2\end{array}$ & Kenc2 & 0.0014 & B & w & [59] \\
\hline Al717104 & potassium inwardly-rectifying channel subfamily J member 14 & Kcnj I4 & 0.0003 & B & w & [59] \\
\hline NM 032073 & potassium voltage-gated channel, subfamily q, member I & Kcnql & 0.0019 & B & w & [59] \\
\hline All 37995 & sodium channel, voltage-gated, type iv, beta & Scn $4 b$ & 0.0087 & B & w & [60] \\
\hline NM 012618 & s 100 calcium-binding protein a 4 & SI00a4 & 0.0066 & $\mathrm{E}$ & $w$ & {$[61]$} \\
\hline NM 053587 & s 100 calcium binding protein a9 (calgranulin b) & S100a9 & 0.0002 & $\mathrm{~F}$ & $w, z$ & {$[62 ; 62]$} \\
\hline$\underline{x 04280}$ & calbindin I & Calb I & 0.0016 & G & $w, z$ & {$[63]$} \\
\hline
\end{tabular}

\section{3. cAMP and adenylate cyclase cascade}

\begin{tabular}{|c|c|c|c|c|c|c|}
\hline MI2672 & guanine nucleotide binding protein, alpha inhibiting 2 & Gnai2 & 0.0028 & A & y & {$[64]$} \\
\hline$\underline{\text { U39572 }}$ & phosphatidylinositol 4-kinase, catalytic, alpha polypeptide & Pik4ca & 0.0096 & A & w & {$[65]$} \\
\hline NM 053926 & phosphatidylinositol-4-phosphate 5-kinase, type ii, alpha & Pip5k2a & 0.0067 & A & w & {$[65]$} \\
\hline BF4I0504 & g-protein-coupled receptor gpr34 & GPR34 & 0.0000 & $\mathrm{D}$ & y & {$[66]$} \\
\hline NM 053456 & phospholipase c-like I & Plcll & 0.0000 & $\mathrm{D}$ & w & {$[67]$} \\
\hline BM386789 & regulator of g-protein signaling I & Rgs I & 0.0071 & $\mathrm{E}$ & w & {$[68]$} \\
\hline $\mathrm{B} 1281632$ & regulator of g-protein signalling 10 & Rgs 10 & 0.0008 & $\mathrm{~F}$ & w & [68] \\
\hline NM $017 / 42$ & adenylyl cyclase 8 & Adcy8 & 0.0098 & G & y & {$[35]$} \\
\hline NM 134386 & g protein-coupled receptor associated sorting protein I & GASPI & 0.0071 & G & $w, y$ & [69] \\
\hline BF56500I & phosphodiesterase $4 d$ & Pde4d & 0.0053 & G & w & {$[70]$} \\
\hline$\underline{\text { AY043246 }}$ & regulator of g-protein signaling 2 & Rgs2 & 0.0003 & G & w & {$[38]$} \\
\hline NM 017214 & regulator of g-protein signaling 4 & Rgs4 & 0.0074 & G & w & [38] \\
\hline NM 080411 & g protein-coupled receptor 83 & Gpr83 & 0.0052 & $\mathrm{H}$ & y & {$[66]$} \\
\hline
\end{tabular}

\section{MAPK cascade}

\begin{tabular}{|c|c|c|c|c|c|c|}
\hline BG664160 & mitogen-activated protein kinase kinase kinase kinase 3 & Map4k3 & 0.0027 & A & w & [34] \\
\hline AF092450 & mitogen activated protein kinase 8 interacting protein & Mapk8i p & 0.0001 & A & w & [34] \\
\hline NM 133545 & protein tyrosine phosphatase $2 \mathrm{e}$ & Ptpn2I & 0.0011 & A & w & [7I] \\
\hline All02620 & mitogen activated protein kinase kinase kinase I & Map3kl & 0.0027 & B & w & [33] \\
\hline $\mathrm{BI} 290864$ & mitogen activated protein kinase kinase kinase 3 & Map3k3 & 0.0098 & B & w & [33] \\
\hline A]271834 & $\begin{array}{l}\text { protein phosphatase Ib, magnesium dependent, beta } \\
\text { isoform }\end{array}$ & Ppmlb & 0.0000 & B & w & [72] \\
\hline BEII3I27 & protein phosphatase 3 , catalytic subunit, alpha isoform & Рpp3ca & 0.0029 & B & w & [72] \\
\hline AA924620 & rab40b, member ras oncogene family & Rab40b & 0.0068 & B & y & [73] \\
\hline $\mathrm{Al2337/2}$ & $\begin{array}{l}\text { protein phosphatase Id magnesium-dependent, delta } \\
\text { isoform }\end{array}$ & Ppmld & 0.0011 & D & y & [72] \\
\hline All 04546 & protein tyrosine phosphatase $4 \mathrm{a} 3$ & Ptp4a3 & 0.0067 & $E$ & y & [72] \\
\hline NM 130403 & protein phosphatase I, regulatory (inhibitor) subunit I4a & PpplrI 4a & 0.0000 & $E$ & y & [72] \\
\hline
\end{tabular}


Table 4: Genes differentially expressed $24 \mathrm{~h}$ or $28 \mathrm{~d}$ following carrageenan injection and known to be involved in pain. (Continued)

\begin{tabular}{|c|c|c|c|c|c|c|}
\hline $\mathrm{A} 1411122$ & rabl, member ras oncogene family & Rabl & 0.0013 & $\mathrm{H}$ & $y$ & [73] \\
\hline \multirow[t]{2}{*}{ BM38484I } & rabI5, member ras onocogene family & Rabl5 & 0.0044 & $\mathrm{H}$ & y & [73] \\
\hline & \multicolumn{6}{|l|}{ 5. Growth factors and related proteins } \\
\hline NM 012513 & brain derived neurotrophic factor & BDNF & 0.0067 & B & $w, z$ & {$[43][42]$} \\
\hline XM 231739 & IGF2 binding protein 3 & $\lg 2 \mathrm{bp} 3$ & 0.0091 & $\mathrm{D}$ & w & [74] \\
\hline NM 013104 & IGF binding protein 6 & Igfbp6 & 0.0020 & $E$ & w & [74] \\
\hline BEI02996 & neurotrophic tyrosine kinase, receptor, type 2 & Ntrk2 & 0.0042 & $E$ & $w$ & [13] \\
\hline \multirow[t]{2}{*}{$\overline{\mathrm{U} 02315}$} & neuregulin I & $\mathrm{Nrgl}$ & 0.0022 & G & $w, z$ & {$[75]$} \\
\hline & \multicolumn{6}{|l|}{$\begin{array}{l}\text { 6. Arachidonic acid cascade and mediators of } \\
\text { inflammation }\end{array}$} \\
\hline NM 138547 & 3-alpha-hydroxysteroid dehydrogenase & & 0.0055 & $\mathrm{C}$ & w & {$[76]$} \\
\hline$\underline{03389}$ & prostaglandin-endoperoxide synthase 2 & $\operatorname{cox} 2$ & 0.0019 & $\mathrm{D}$ & w & [77] \\
\hline$\underline{04488}$ & prostaglandin $\mathrm{d} 2$ synthase & Ptgds & 0.0017 & $E$ & w & [78] \\
\hline NM 017020 & interleukin 6 receptor & $116 \mathrm{ra}$ & 0.0030 & $\mathrm{~F}$ & w & [76] \\
\hline AA851740 & interleukin 6 signal transducer & $116 s t$ & 0.0025 & $\mathrm{~F}$ & w & [76] \\
\hline NM 13355I & phospholipase a2, group $4 a$ & $\mathrm{Pla} 2 \mathrm{~g} 4 \mathrm{a}$ & 0.0024 & $\mathrm{~F}$ & w & [79] \\
\hline \multirow[t]{2}{*}{ AA893169 } & tissue inhibitor of metalloproteinase 3 & Timp3 & 0.0060 & $\mathrm{~F}$ & w & [9] \\
\hline & \multicolumn{6}{|l|}{ 7. Others } \\
\hline NM 012823 & annexin a3 & Anxa3 & 0.0026 & A & $w, z$ & [14] \\
\hline$\overline{\mathrm{B} 1281979}$ & microtubule-associated proteins $\mathrm{Ib}$ & Mapllc 3b & 0.0076 & A & $y, z$ & {$[15]$} \\
\hline$\overline{A B 011679}$ & tubulin, beta 5 & Tubb5 & 0.0019 & $A$ & $y$ & [17] \\
\hline NM 023974 & synaptoporin & Synpr & 0.0009 & B & $y, z$ & [16] \\
\hline NM 012551 & early growth response I & Egrl & 0.0037 & B & w & [29] \\
\hline $\mathrm{BI} 294912$ & proteasome subunit, alpha type 3 & Psma3 & 0.0020 & $\mathrm{D}$ & w & [80] \\
\hline $\mathrm{B} 1283657$ & chaperonin subunit 4 (delta) & Cct4 & 0.0001 & $\mathrm{~F}$ & $y$ & {$[18]$} \\
\hline BG372598 & neural cell adhesion molecule I & Ncam I & 0.0045 & $\mathrm{~F}$ & $w, z$ & {$[81]$} \\
\hline NM 012755 & fyn proto-oncogene & Fyn & 0.0010 & $\mathrm{E}$ & $w$ & [19] \\
\hline
\end{tabular}

For cluster description see Result and Figure 3.

Selection criteria:

$\mathbf{w}$ - involved in pain-related pathways.

$\mathbf{y}$-interact with or regulate protein involved in pain perception.

z- expression level is altered in different model of pain.

hyperalgesia-related memory. The enhanced hyperalgesia is present even 28 days after the initial injection [7].

In this study we found alterations of gene expression that lasted at least $28 \mathrm{~d}$ and were quite different from transitory changes observed $24 \mathrm{~h}$ after injection. The genes altered at $24 \mathrm{~h}$ include those involved in immune reaction and protein synthesis (Table 2), whereas long-lasting changes observed 28 days after injection indicate different pathways, most notably those responsible for new synapse formation (Table 3).

The observed short-term upregulation of the immune response genes concurs with earlier reports that IL-6 $[20,21]$ and TNF-a (tumor necrosis factor-a) [21] play an important role in inflammatory pain. The upregulation of these genes had previously been associated with the development of neuropathic pain as well [22]. A similar result has been found following nerve injury and spinal cord injury (SCI). SCI induces a robust and significant increase in mRNAs of inflammatory cytokines such as TNF-a, interleukin-1 $\beta$ (IL-1 $\beta$ ), and IL-6 at 1, 3, and 24 h post-injury [23-25]. We do not know whether the changes in gene expression are mediated by inflammation, pain, possible injury to the nerve, or a combination thereof.

We observed significant changes in expression of several key enzymes (3-alpha-hydroxysteroid dehydrogenase, phospholipase a2, prostaglandin $\mathrm{d} 2$ synthase, and COX2) involved in eicosanoid biosynthesis (Table 4, Arachidonic acid cascade and mediators of inflammation). This cascade is usually initiated by the activation of phospholipase A2 and the release of arachidonic acid (AA) [26]. The AA is subsequently transformed by cyclooxygenase (COX) and lipoxygenase pathways to prostaglandins, thromboxane, and leukotrienes, collectively termed eicosanoids. Eicosanoid production is considerably increased during inflammation and inflammation-induced pain, and COX 


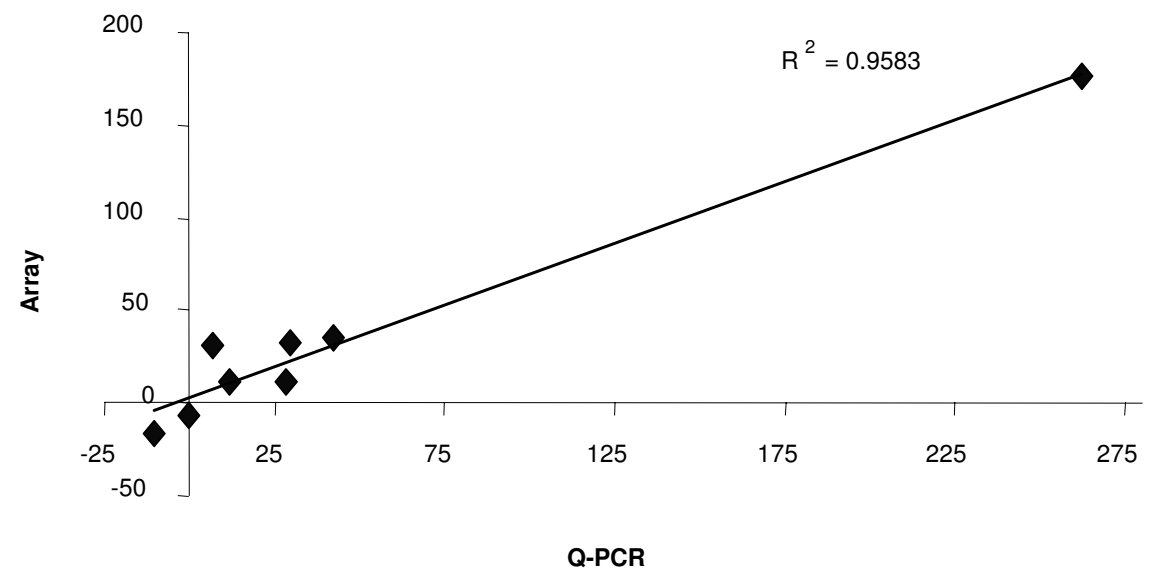

\begin{tabular}{|l|l|c|c|c|c|c|}
\hline \multicolumn{2}{|c|}{} & control & 28d-group & p-value & \multicolumn{3}{|c|}{ relative expression (\%) } \\
\hline Icn2 & lipocalin 2 & $57.2 \pm 2.5$ & $51.3 \pm 2.6$ & 0.22 & -10.3 & -16.0 \\
\hline gabra6 & GABA A receptor alpha 6 & $91.1 \pm 13.5$ & $90.7 \pm 13.2$ & 0.99 & -0.4 & -7.3 \\
\hline S100a4 & S100 calcium-binding protein A4 & $69.8 \pm 6.8$ & $74.5 \pm 7.5$ & 0.66 & 6.6 & 31.6 \\
\hline ptgds & prostaglandin D synthetase & $75.4 \pm 2.6$ & $84.2 \pm 3.2$ & 0.03 & 11.6 & 10.9 \\
\hline insig1 & insulin-induced gene 1 & $86.4 \pm 6.2$ & $110.9 \pm 8.1$ & 0.03 & 28.3 & 11.0 \\
\hline mmp14 & matrix metalloproteinase 14 & $69.2 \pm 9.1$ & $89.8 \pm 6.2$ & 0.07 & 29.8 & 32.5 \\
\hline igf1 & insulin-like growth factor 1 & $61.4 \pm 7.4$ & $87.5 \pm 6.1$ & 0.05 & 42.6 & 35.0 \\
\hline ca3 & carbonic anhydrase 3 & $29.8 \pm 13.3$ & $108.0 \pm 17.9$ & 0.01 & 262.3 & 175.9 \\
\hline
\end{tabular}

\section{Figure 4}

Comparison of microarray and Q-PCR results. Equal amounts of total RNA from each sample have been used for PCR amplification. The results were corrected for difference in PCR efficiency based on the dilution curves for each gene. Each gene expression was normalized to reference genes (sepI5 and gtpbp4) to correct for possible error in RNA measurement. Data presented as expression relative to reference genes \pm SEM. There were 8 control and $928 \mathrm{~d}$-group samples. $p$-value is unpaired t-test. Relative expression is presented as percentage of control.

is the major target for nonsteroidal antiinflammatory drugs (NSAIDs). It is possible that activation of eicosanoids by inflammation/pain causes lasting changes in gene expression. NMDA receptors, which are prominently involved in activity-dependent synaptic plasticity and tonic pain [27], could mediate the upregulation of inflammatory factors. Inflammation-induced NMDAR activation involves phosphorylation of the NR1 and NR2B subunits in the spinal dorsal horn by fyn proto-oncogene [28]. The downstream changes in Egr1, MAPK, and AC expression (see Table 4) can be also induced by activation of the NMDA receptor. As an alternative, activation of the neurotensin receptor can stimulate Egr1 expression and MAP kinase pathways [29].
We do not know whether activation of eicosanoids and MAP kinases is part of one inflammatory/pain pathway or the former is the result of inflammation and the latter is pain-induced. In any case, long-lasting changes in gene expression are unlikely to be induced by ongoing inflammation, since the majority of genes known to be involved directly in the inflammatory response have a profile with maximum changes at $24 \mathrm{~h}$ and returning to control levels $28 \mathrm{~d}$ following injection. No detectable changes of inflammatory cytokine genes, including those described above, were found $28 \mathrm{~d}$ after injection. However, initial inflammatory response may contribute to long-term changes in gene expression and pain memory. A number of genes altered in the $28 \mathrm{~d}$ group are involved in inflammationinduced potentiation of pain sensitivity. For example, 
dynorphin [30,31], neuropeptide Y (NPY), and NPY (Y1) receptor [32] are induced in the spinal cord by peripheral inflammation. However, it is unknown whether activation of nociceptors is required.

Based on our expression data, carrageenan injection affected at least two signal transduction pathways, MAPK and cAMP/adenylyl cyclase (AC), known to regulate nociceptive signal perception and transmission. Several isoforms of MAPK are involved in regulation of acute and chronic pain both in neuron and glial cells $[33,34]$. cAMP mediates many aspects of pain transmission within neuronal cells. In particular, AC isoform 8 (AC8) that couples NMDA receptor activation to CAMP signaling pathways in neurons are important in the development of persistent pain [35]. Activation of MAPK cascade might be mediated by neurotensin receptor via Egr1, which is known to be upregulated in response to persistent inflammatory pain [29] and stimulates Erk1/2 phosphorylation [36]. It is likely that an interaction between the glutamate pathway and CAMP signaling is mediated by modulation of metabotropic glutamate receptor by RGS2 and RGS4 [37,38], which were downregulated $24 \mathrm{~h}$ after carrageenan injection (Table 4). Based solely on our data, we cannot tell whether the trigger for long-term changes in gene expression is the initial inflammation or pain or their combination. It is also unlikely that all changes in gene expression observed in the $28 \mathrm{~d}$ group are related to formation and maintenance of nociceptive memory. However, the prominent group (Table 3) of differentially expressed genes controls neuronal connectivity, synaptogenesis, and neurogenesis. It is known that long-term memory and plasticity in CNS depend on formation of new synapses that require synthesis of proteins responsible for cell-to-cell interaction-in particular cadherin-like protein. There is also evidence that formation of new neurons is important for memory formation and plasticity [39].

There is similarity in the development of long-term potentiation (LTP), long-term memory, and pain. Research indicates that central sensitization in the spinal cord has the identical mechanism to LTP [40]. We have found that a number of genes altered at $28 \mathrm{~d}$ were also altered in the hippocampus during LTP: brain-derived neurotrophic factor (BDNF), early growth response 1 (EGR1), CD9 antigen (CD9), neuropeptide Y receptor Y5 (NPY5R), and neuropeptide $\mathrm{Y}$ receptor (NPY1R) [41]. Genes such as BDNF [13,42], NtrkB (BDNF receptor), Egr1 [29], neuropeptide $\mathrm{Y}$ receptor, and neuregulin1 are also known to be involved in inflammation-induced pain. For example, BDNF, a known modulator of memory, was found to be altered in rat pups one day after peripheral inflammation induced by injection of Freund's complete adjuvant [43]. We do not believe, however, that pain memory and LTP are identical phenomena but rather share some basic mechanisms. They have different anatomical substrates, and most alterations found in our study were not observed in the hippocampus following memory formation. Based on our data, pain or inflammation or a combination thereof induces dramatic changes in gene expression. Most of these changes in gene expression subside when inflammation disappears, while some of them persist and even increase $28 \mathrm{~d}$ later. Thus, part of the painand inflammation-induced changes in gene expression belong to pathway(s) that remain activated long after inflammation and acute pain disappear. We can only speculate which genes whose expression increased much more at $28 \mathrm{~d}$ than at $24 \mathrm{~h}$ belong to these pathways. Additional experiments are needed to narrow down the list of affected pathways. Based on the results of GO analysis, proteins involved in synaptogenesis, cell-cell interaction, and the formation of new neurons are overrepresented among differentially expressed genes at $28 \mathrm{~d}$ after carrageenan injection. Thus, we propose that pathways related to synapse formation between newly generated neurons are particularly important for "pain memory." The tentative nature of this conclusion depends on the exploratory nature of our microarray data and analysis. The selection of genes is based on a limited number of replicates and multiple comparisons, which implies that a number of genes may be false positives. We confirmed the differential expression for a few selected genes by PCR, but more research is needed to complete verification of the microarray data.

\section{Conclusion}

We have observed long-lasting changes in gene expression following recovery from carrageenan-induced hyperalgesia. On the basis of these data, we propose that pathways related to synapse formation are involved in the formation of pain memory.

\section{Methods}

The study was approved by the Harvard Medical Area Standing Committee on Animals, Harvard Medical School. Experiments were performed on male SpragueDawley rats weighing 250-300 g that were housed with a 12-h light-dark cycle and food and water available ad libitum.

Gene expression in the lumbar part of the spinal cord was compared in three groups of rats: $28 \mathrm{~d}$ after carrageenan injection, 24h after carrageenan injection, and a control group without injection.

Inflammation was induced by injection (26-gauge needle) of $0.1 \mathrm{ml}$ of $2 \%$ carrageenan (Sigma Chemical Co., St. Louis, MO) in the plantar surface of the hind paw under halothane $(2 \%)$ anesthesia. The rat paw volume was measured by a plethysmometer (Paw Volume Meter; Ugo 
Basile). The general procedure for measuring changes in behavioral responses for microarray experiments was as follows: For several days after arrival, rats were placed in the testing environment, and during the two days preceding the experiment, pressure threshold and hind paw volumes were measured. On the experimental day, basal values were determined twice with a 30-min interval; the average value of two readings was used as a baseline. The rats were assigned randomly (blocked randomization) to one of three groups. Carrageenan was injected into the right hind paw, and the rat was decapitated $24 \mathrm{~h}$ or $28 \mathrm{~d}$ after injection. Paw volume was measured on both sides $2 \mathrm{~h}, 4 \mathrm{~h}, 24 \mathrm{~h}$, and $28 \mathrm{~d}$ after each of the carrageenan injections. We assumed that pain-related memory is most likely mediated by altered gene expression both in ipsilateral and contralateral parts of the lumbar enlargement of the spinal cord. In this study we have limited the measurement of gene expression to the ipsilateral portion that is most affected by carrageenan injection.

\section{RNA isolation and Affymetrix GeneChip processing}

The spinal cord was removed under hydraulic pressure with 10-ml syringe with saline [44], and the lumbar enlargement was dissected into ipsi- and contralateral parts and frozen. Tissues were kept at $-80^{\circ} \mathrm{C}$ until RNA isolation.

Total RNA was isolated by quickly homogenizing the tissue at high speed in Trizol (Invitrogen, Carlsbad, CA) according to the manufacturer's instructions. The concentration of total RNA was measured by UV spectrophotometry, and RNA quality was confirmed by electrophoresis in $1 \%$ agarose gel and Agilent bioanalyzer (Agilent Technologies, Inc, Santa Clara CA). Only those samples that had a 260/280 ratio more than 1.9 and had no signs of degradation based on agarose electrophoresis were used for analysis. The RNA samples were stored at $-80^{\circ} \mathrm{C}$.

Gene expression analyses were performed with the Affymetrix Rat Genome 230 v.2 chip (Affymetrix, Santa Clara, CA), which contains $\sim 31,000$ probe sets including $\sim 17,000$ annotated rat genes. For each chip, RNA from the spinal cord of 3 rats was pooled to minimize interindividual variability. Pooled spinal cord RNA from the control, $24 \mathrm{~h}$, and $28 \mathrm{~d}$ groups was hybridized in triplicate to the Affymetrix 230 rat microarray, so that 9 animals were used per treatment group. The labeling, hybridization, and scanning were done through the NIH Neuroscience Microarray Consortium at Affymetrix GeneChip Resource, W. M. Keck Facility, Yale University School of Medicine, according to Affymetrix protocol using recommended equipment. The DNA chips were scanned by confocal scanner. Digitized image data were processed the MAS software (version 5.0) from Affymetrix. The expression data reported in this paper have been deposited in the
National Center for Biotechnology Information Gene Omnibus database.

\section{Microarray Data Analysis}

The resulting microarray data that passed quality control tests were imported into the Rosetta Resolver system for gene expression data analysis (Rosetta Biosoftware, Kirkland, WA). While it was imported, the microarray data were subjected to background correction, intrachip normalization, and the Rosetta Resolver system Affymetrix GeneChip error model. The intensity profiles that are generated were used to build ratios with Rosetta Resolver Ratio Builder. Briefly, the first step in data analysis includes validation of each probe set based on empirical error distribution and removal of the probe pairs that are beyond three standard deviations from the mean. Probelevel data were used to increase robustness by calculating the averages. The expression values for individual profiles were combined using an error-weighted average in a transformed space, and the error of the result was adjusted correspondingly. All profiles belonging to one single experiment are normalized together. We have used global normalization based on weighted average. The Ratio Builder was used calculate ratio probabilities for the differential expression among the control, 24h, and 28d groups. More detailed information on the Rosetta Resolver system Affymetix GeneChip error model, errorweighted statistical model, and ratio building error model can be found at Rosetta Resolver web site and in publications of Hughes et al. [45,46]. As a result of analysis, genes were assigned p-values reflecting differences between the control and injected groups. The p-values were used to select genes for further clustering and functional classification. Thus, the analysis of data was based on the combination of two procedures: Resolver error model and selforganizing map (SOM) clustering complemented by functional classification using DAVID [47]. We have used Affy chip background since more specific list of gene related to spinal cord expression is not available. SOM was applied by the weighted pair-group method with centered average and Pearson correlation implemented in the program xCluster (kindly provided by Gavin Sherlock, Stanford University). The differentially expressed genes were clustered according to their expression in $24 \mathrm{~h}$ and $28 \mathrm{~d}$ groups. Statistical differences within cluster were evaluated with one way ANOVA followed by Scheffe test. At the next step, the same genes differentially expressed at $28 \mathrm{~d}$ and $24 \mathrm{~h}$ were functionally classified by gene ontology. We also clustered genes known to be involved in inflammation using SOM. In order to organize selected genes according to the intracellular pathways involved, we used a contextbased information search and graphical tools (GeneSphere, Malden, MA). 
Table 5: Sequence of primers for PCR verification.

\begin{tabular}{lll}
\hline Gene & Forward Primer & Reverse Primer \\
\hline gtpbp & CAG CCA AGG ACT TTA TTG ACC & GTC GCA CGT AAT CTT TAG CAA C \\
sepl5. & GAG AAG CTG GAA CGC ATA TAA G & GGG CTA CTT CAG CTT CGA AT \\
ca3 & CAC TGG AAC CCG AAG TAT AAC A & CGC CTT TCT CCC GTC CTA \\
gabra6 & CAA GCC CCC GGT AGC AAA G & TGA CCG GCG TTG ATG GTA AGA T \\
lgfl & AGC CAA GAC AGA TAG CCA TAC A & AAG CAG AGT GCC AGG TAG AAG \\
Insigl & CGC TCT TCC CGG ACG AG & CCA CCA CAA GCC CAA GGA TAG G \\
Icn2 & ACT TCA AAG TCA CCC TGT ACG G & ATC CCA GTC AGC CAC GCT CAC \\
mmpl4 & TCA GGG CAG TGG ACA GCG AAT A & AGC ACC GGC AGA ACG AC \\
ptgds & CGG GAG AAG AAA GAG CTA CTG T & GGG CTG TTG TAG GTG TAC TGT C \\
sl00a4 & GGC CCT GGA TGT AAT AGT GTC & GCC CTC AAA GAA TTC ATT GCA C \\
\hline
\end{tabular}

The primers were designed using Oligo software (Molecular Biology Insights, Inc, Cascade, CO)

The selection of genes known to be involved in pain perception (Table 3) was based on gene ontology and a context-based information search of PubMed-indexed publications using the following criteria: a. protein involved in pain-related pathways; b. gene expression altered in different pain model; c. interaction with protein involved in pain (Table 4).

\section{RT-PCR Verification}

Quantitative RT-PCR was used to verify the microarray results for six randomly selected differentially expressed genes and two genes that were not differentially expressed on the gene array (negative control). RNA was extracted from each animal as described above and cDNA was synthesized using superscript reverse transcriptase (Invitrogen). PCR amplification used sybr green gene mix from Biorad (Hercules, CA). Cycling parameters were $95^{\circ} \mathrm{C}$ for $10 \mathrm{~min}$ followed by 40 cycles of $95^{\circ} \mathrm{C}$ for $30 \mathrm{sec}$, Ta ${ }^{\circ} \mathrm{C}$ for $40 \mathrm{sec}$, and $72^{\circ} \mathrm{C}$ for $90 \mathrm{sec}$. Primers sequences are summarized in Table 5. Amplification of each gene was expressed as the amplification cycle at which its PCR product was first detected (threshold cycle, CT). All samples were run at the same plate. The relative quantification of the target gene expression was performed according to the comparative CT method ( $\Delta \Delta \mathrm{CT}$ method). For each run, the mean expression levels of target genes were normalized to the mean expression levels of two endogenous reference genes (sep15 and gtpbp4). Serial dilution of standard cDNA was used to correct for difference in amplification efficiency. The "standard" cDNA for the entire study was generated from a tissue homogenate, which was obtained by pooling cDNA from all control rats. PCR buffer and RNA were used as a negative control. The resulting data were analyzed with unpaired t-test. The Pearson correlation coefficient was used to compare fold changes on gene arrays with those found on RT-PCR.

\section{Competing interests}

The author(s) declare that they have no competing interests.

\section{Authors' contributions}

RY- design, data collection and analysis of microarray data, manuscript preparation IK - design, interpretation of data, manuscript preparation

\section{Additional material}

\section{Additional file 1}

The list of differentially expressed genes. The list of genes differentially expressed with $p<0.01$ at $24 \mathrm{~h}$ and $28 \mathrm{~d}$ following injection of carrageenan with a brief description and relative expression value. Click here for file

[http://www.biomedcentral.com/content/supplementary/14712202-9-32-S1.xls]

\section{Acknowledgements}

We appreciate the help from Cristina Freitas with our behavioral experiments.

This study was supported by an NIH ROI to I. Kissin.

\section{References}

I. Kehlet $\mathrm{H}$, Jensen TS, Woolf $\mathrm{CJ}$ : Persistent postsurgical pain: risk factors and prevention. Lancet 2006, 367:1618-1625.

2. Tasmuth T, Estlanderb AM, Kalso E: Effect of present pain and mood on the memory of past postoperative pain in women treated surgically for breast cancer. Pain 1996, 68:343-347.

3. Katz J, Jackson M, Kavanagh BP, Sandler AN: Acute pain after thoracic surgery predicts long-term post-thoracotomy pain. Clin J Pain 1996, I 2:50-55.

4. Callesen $\mathrm{T}$, Bech $\mathrm{K}$, Kehlet $\mathrm{H}$ : Prospective study of chronic pain after groin hernia repair. Br J Surg 1999, 86:1528-153I.

5. Guilbaud G, Kayser V, Attal N, Benoist J-M: Evidence for a central contribution to secondary hyperalgesia. In Hyperalgesia and Allodynia Edited by: Willis WD. New York: Raven Press; 1992:187-201.

6. Aley KO, Messing RO, Mochly-Rosen D, Levine JD: Chronic hypersensitivity for inflammatory nociceptor sensitization medi- 
ated by the epsilon isozyme of protein kinase C. J Neurosci 2000, 20:4680-4685.

7. Kissin I, Freitas CF, Bradley ELJ: Memory of pain: the effect of perineural resiniferatoxin. Anesth Analg 2006, 103:72I-728.

8. Wang H, Sun H, Della PK, Benz RJ, Xu J, Gerhold DL, et al.: Chronic neuropathic pain is accompanied by global changes in gene expression and shares pathobiology with neurodegenerative diseases. Neuroscience 2002, I I 4:529-546.

9. Rodriguez PJ, Korostynski M, Kaminska-Chowaniec D, Obara I, Mika J, Przewlocka B, et al.: Comparison of gene expression profiles in neuropathic and inflammatory pain. J Physiol Pharmacol 2006, 57:40I-4I4.

10. Costigan M, Befort K, Karchewski L, Griffin RS, D'Urso D, Allchorne $A$, et al.: Replicate high-density rat genome oligonucleotide microarrays reveal hundreds of regulated genes in the dorsal root ganglion after peripheral nerve injury. BMC Neurosci 2002 , 3:16.

II. Loguinov A, Anderson L, Crosby GJ, Yukhananov RY: Gene expression following acute administration of morphine. Physiological Genomics 2001, 6:169-181.

12. Morey JS, Ryan JC, Van Dolah FM: Microarray validation: factors influencing correlation between oligonucleotide microarrays and real-time PCR. Biol Proced Online 2006, 8: I75-193.

13. Obata $K$, Noguchi $K$ : BDNF in sensory neurons and chronic pain. Neurosci Res 2006, 55:1-10.

14. Sjostrand C, Duvefelt K, Steinberg A, Remahl IN, Waldenlind E, Hillert J: Gene expression profiling in cluster headache: a pilot microarray study. Headache 2006, 46:1518-1534.

15. Kim DS, Lee SJ, Park SY, Yoo HJ, Kim SH, Kim KJ, et al.: Differentially expressed genes in rat dorsal root ganglia following peripheral nerve injury. Neuroreport 200I, I 2:340I-3405.

16. Sun T, Xiao HS, Zhou PB, Lu YJ, Bao L, Zhang X: Differential expression of synaptoporin and synaptophysin in primary sensory neurons and up-regulation of synaptoporin after peripheral nerve injury. Neuroscience 2006, I 4 I: | 233- I 245.

17. Goswami C, Dreger M, Jahnel R, Bogen O, Gillen C, Hucho F: Identification and characterization of a $\mathrm{Ca2}+$-sensitive interaction of the vanilloid receptor TRPVI with tubulin. J Neurochem 2004, 91 : 1092-1 03.

18. Lee MJ, Stephenson DA, Groves MJ, Sweeney MG, Davis MB, An SF, et al: Hereditary sensory neuropathy is caused by a mutation in the delta subunit of the cytosolic chaperonin-containing tcomplex peptide-I (Cct4) gene. Hum Mol Genet 2003, 12:1917-1925.

19. Abe T, Matsumura S, Katano T, Mabuchi T, Takagi K, Xu L, et al: Fyn kinase-mediated phosphorylation of NMDA receptor NR2B subunit at Tyrl472 is essential for maintenance of neuropathic pain. Eur J Neurosci 2005, 22: | 445- I 454.

20. De Jongh RF, Vissers KC, Meert TF, Booij LH, De Deyne CS, Heylen $\mathrm{RJ}$ : The role of interleukin-6 in nociception and pain. Anesth Analg 2003, 96: 1096-103. table

21. Verri WAJ, Cunha TM, Parada CA, Poole S, Cunha FQ, Ferreira SH: Hypernociceptive role of cytokines and chemokines: targets for analgesic drug development? Pharmacol Ther 2006, I 1 2:116-138.

22. Schafer M: Cytokines and peripheral analgesia. Adv Exp Med Biol 2003, 521:40-50.

23. Song G, Cechvala C, Resnick DK, Dempsey RJ, Rao VL: GeneChip analysis after acute spinal cord injury in rat. J Neurochem 200I, 79:804-8I5.

24. Wang CX, Nuttin B, Heremans H, Dom R, Gybels J: Production of tumor necrosis factor in spinal cord following traumatic injury in rats. J Neuroimmunol 1996, 69:151-156.

25. Bartholdi D, Schwab ME: Expression of pro-inflammatory cytokine and chemokine mRNA upon experimental spinal cord injury in mouse: an in situ hybridization study. Eur $\int \mathrm{Neu}-$ rosci 1997, 9: | 422-1438.

26. Khanapure SP, Garvey DS, Janero DR, Letts LG: Eicosanoids in inflammation: biosynthesis, pharmacology, and therapeutic frontiers. Curr Top Med Chem 2007, 7:3 I I-340.

27. Woolf CJ, Salter MW: Neuronal plasticity: increasing the gain in pain. Science 2000, 288: $1765-1769$.

28. Guo W, Zou S, Guan Y, Ikeda T, Tal M, Dubner R, et al.: Tyrosine phosphorylation of the NR2B subunit of the NMDA receptor in the spinal cord during the development and maintenance of inflammatory hyperalgesia. J Neurosci 2002, 22:6208-62I7.
29. Ko SW, Vadakkan KI, Ao H, Gallitano-Mendel A, Wei F, Milbrandt J, et al.: Selective contribution of Egrl (zif/268) to persistent inflammatory pain. J Pain 2005, 6:12-20.

30. Noguchi K, Kowalski K, Traub R, Solodkin A, ladarola MJ, Ruda MA Dynorphin expression and Fos-like immunoreactivity following inflammation induced hyperalgesia are colocalized in spinal cord neurons. Brain Res Mol Brain Res 1991, 10:227-233.

31. Dubner R, Ruda MA: Activity-dependent neuronal plasticity following tissue injury and inflammation. Trends Neurosci 1992, 15:96-103.

32. Ji RR, Zhang $X$, Wiesenfeld-Hallin Z, Hokfelt $T$ : Expression of neuropeptide $Y$ and neuropeptide $Y(Y I)$ receptor $m R N A$ in rat spinal cord and dorsal root ganglia following peripheral tissue inflammation. J Neurosci 1994, 14:6423-6434.

33. Ji RR: Peripheral and central mechanisms of inflammatory pain, with emphasis on MAP kinases. Curr Drug Targets Inflamm Allergy 2004, 3:299-303.

34. Obata K, Noguchi K: MAPK activation in nociceptive neurons and pain hypersensitivity. Life Sci 2004, 74:2643-2653.

35. Vadakkan KI, Wang H, Ko SW, Zastepa E, Petrovic MJ, Sluka KA, et al.: Genetic reduction of chronic muscle pain in mice lacking calcium/calmodulin-stimulated adenylyl cyclases. Mol Pain 2006, 2:7.

36. Zhao D, Zhan Y, Zeng H, Koon HW, Moyer MP, Pothoulakis C: Neurotensin stimulates expression of early growth response gene-I and EGF receptor through MAP kinase activation in human colonic epithelial cells. Int J Cancer 2007, 120: I 652- 1656.

37. Neugebauer V: Metabotropic glutamate receptors-important modulators of nociception and pain behavior. Pain 2002, 98:I-8.

38. De Blasi A, Conn PJ, Pin J, Nicoletti F: Molecular determinants of metabotropic glutamate receptor signaling. Trends Pharmacol Sci 200I, 22:114-120.

39. Shors T], Miesegaes G, Beylin A, Zhao M, Rydel T, Gould E: Neurogenesis in the adult is involved in the formation of trace memories. Nature 200I, 410:372-376.

40. Sandkuhler J: Understanding LTP in pain pathways. Mol Pain 2007, 3:9.

4I. Bailey CH, Bartsch D, Kandel ER: Toward a molecular definition of long-term memory storage. Proc Natl Acad Sci USA 1996, 93:13445-13452.

42. Groth R, Aanonsen L: Spinal brain-derived neurotrophic factor (BDNF) produces hyperalgesia in normal mice while antisense directed against either BDNF or trkB, prevent inflammation-induced hyperalgesia. Pain 2002, 100:17I-181.

43. Chien CC, Fu WM, Huang HI, Lai YH, Tsai YF, Guo SL, et al.: Expression of neurotrophic factors in neonatal rats after peripheral inflammation. J Pain 2007, 8:161-167.

44. Meikle AD, Martin AH: A rapid method for removal of the spinal cord. Stain Technology I98I, 56:235-237.

45. Hughes TR, Marton MJ, Jones AR, Roberts CJ, Stoughton R, Armour $C D$, et al.: Functional discovery via a compendium of expression profiles. Cell 2000, 102:109-126.

46. Roberts CJ, Nelson B, Marton MJ, Stoughton R, Meyer MR, Bennett HA, et al.: Signaling and circuitry of multiple MAPK pathways revealed by a matrix of global gene expression profiles. Science 2000, 287:873-880.

47. Dennis G], Sherman BT, Hosack DA, Yang J, Gao W, Lane HC, et al: DAVID: Database for Annotation, Visualization, and Integrated Discovery. Genome Biol 1907, 4:3.

48. Okamoto K, Imbe H, Morikawa Y, Itoh M, Sekimoto M, Nemoto K, et al.: 5-HT2A receptor subtype in the peripheral branch of sensory fibers is involved in the potentiation of inflammatory pain in rats. Pain 2002, 99:133-143.

49. Wu S, Zhu M, Wang W, Wang Y, Li Y, Yew DT: Changes of the expression of 5-HT receptor subtype mRNAs in rat dorsal root ganglion by complete Freund's adjuvant-induced inflammation. Neurosci Lett 200I, 307:183-186.

50. Dickinson T, Fleetwood-Walker SM: VIP and PACAP: very important in pain? Trends Pharmacol Sci 1999, 20:324-329.

5I. Wiesenfeld-Hallin Z, Xu XJ, Crawley JN, Hokfelt T: Galanin and spinal nociceptive mechanisms: recent results from transgenic and knock-out models. Neuropeptides 2005, 39:207-2 I0.

52. Brumovsky P, Shi TS, Landry M, Villar MJ, Hokfelt T: Neuropeptide tyrosine and pain. Trends Pharmacol Sci 2007, 28:93-102. 
53. Martin TJ, Eisenach JC, Misler J, Childers SR: Chronic activation of spinal adenosine $A$ I receptors results in hypersensitivity. Neuroreport 2006, 17:1619-1622.

54. Sarret P, Esdaile MJ, Perron A, Martinez J, Stroh T, Beaudet A: Potent spinal analgesia elicited through stimulation of NTS2 neurotensin receptors. INeurosci 2005, 25:8|88-8|96.

55. Lai J, Ossipov MH, Vanderah TW, Malan TPJ, Porreca F: Neuropathic pain: the paradox of dynorphin. Mol Interv 200I, I: $160-167$

56. Miki K, Fukuoka T, Tokunaga A, Noguchi K: Calcitonin generelated peptide increase in the rat spinal dorsal horn and dorsal column nucleus following peripheral nerve injury: upregulation in a subpopulation of primary afferent sensory neurons. Neuroscience 1998, 82:1243-1252.

57. Bleakman D, Alt A, Nisenbaum ES: Glutamate receptors and pain. Semin Cell Dev Biol 2006, 17:592-604.

58. Smith PA, Moran TD, Abdulla F, Tumber KK, Taylor BK: Spinal mechanisms of NPY analgesia. Peptides 2007, 28:464-474.

59. Ocana M, Cendan CM, Cobos EJ, Entrena JM, Baeyens JM: Potassium channels and pain: present realities and future opportunities. Eur J Pharmacol 2004, 500:203-219.

60. Amir R, Argoff CE, Bennett G], Cummins TR, Durieux ME, Gerner P, et al: The role of sodium channels in chronic inflammatory and neuropathic pain. J Pain 2006, 7:SI-29.

61. Sandelin M, Zabihi S, Liu L, Wicher G, Kozlova EN: Metastasis-associated SI O0A4 (MtsI) protein is expressed in subpopulations of sensory and autonomic neurons and in Schwann cells of the adult rat. J Comp Neurol 2004, 473:233-243.

62. Dale CS, Pagano RL, Paccola CC, Pinotti-Guirao T, Juliano MA, Juliano $L$, et al.: Effect of the C-terminus of murine SI00A9 protein on experimental nociception. Peptides 2006, 27:2794-2802.

63. Mineta $Y$, Koyanagi $H$, Morimoto M, Harano K, Totoki T, Jacobowitz DM: Immunocytochemical study of parvalbumin, calbindin D-28k, and calretinin in the superficial dorsal horn of the rat spinal cord following unilateral hindpaw inflammation. J Anesthesia 1996, 10:211-217.

64. Traynor JR, Neubig RR: Regulators of $\mathbf{G}$ protein signaling \& drugs of abuse. Mol Interv 2005, 5:30-4I.

65. Liu B, Zhang C, Qin F: Functional recovery from desensitization of vanilloid receptor TRPVI requires resynthesis of phosphatidylinositol 4,5-bisphosphate. J Neurosci 2005, 25:4835-4843.

66. Bedard A, Tremblay P, Chernomoretz A, Vallieres L: Identification of genes preferentially expressed by microglia and upregulated during cuprizone-induced inflammation. Glia 2007 55:777-789.

67. Narita M, Ohsawa M, Mizoguchi H, Aoki T, Suzuki T, Tseng LF: Role of the phosphatidylinositol-specific phospholipase $C$ pathway in delta-opioid receptor-mediated antinociception in the mouse spinal cord. Neuroscience 2000, 99:327-33I.

68. Xie Z, Li Z, Guo L, Ye C, Li J, Yu X, et al.: Regulator of G protein signaling proteins differentially modulate signaling of mu and delta opioid receptors. Eur J Pharmacol 2007, 565:45-53.

69. Martini L, Waldhoer M, Pusch M, Kharazia V, Fong J, Lee JH, et al.: Ligand-induced down-regulation of the cannabinoid I receptor is mediated by the G-protein-coupled receptor-associated sorting protein GASPI. FASEB J 2007, $21: 802-81$ I.

70. Cunha FQ, Teixeira MM, Ferreira SH: Pharmacological modulation of secondary mediator systems-cyclic AMP and cyclic GMP-on inflammatory hyperalgesia. Br J Pharmacol 1999, 127:67|-678.

71. Durham P, Russo A: New insights into the molecular actions of serotonergic antimigraine drugs. Pharmacol Ther 2002, 94:77-92.

72. Zhang $X, W u$ J, Fang L, Willis WD: The effects of protein phosphatase inhibitors on nociceptive behavioral responses of rats following intradermal injection of capsaicin. Pain 2003 106:443-45I.

73. Bron R, Klesse LJ, Shah K, Parada LF, Winter J: Activation of Ras is necessary and sufficient for upregulation of vanilloid receptor type $I$ in sensory neurons by neurotrophic factors. Mol Cell Neurosci 2003, 22: I 18-132.

74. Ishii DN: Implication of insulin-like growth factors in the pathogenesis of diabetic neuropathy. Brain Res Brain Res Rev $1995,20: 47-67$
75. Lacroix-Fralish ML, Tawfik VL, Nutile-McMenemy N, DeLeo JA: Neuregulin $I$ is a pronociceptive cytokine that is regulated by progesterone in the spinal cord: Implications for sex specific pain modulation. Eur J Pain 2007.

76. Sommer C, Kress M: Recent findings on how proinflammatory cytokines cause pain: peripheral mechanisms in inflammatory and neuropathic hyperalgesia. Neurosci Lett 2004, 361:184-187.

77. Zeilhofer HU: Prostanoids in nociception and pain. Biochem Pharmacol 2007, 73:165-174.

78. Eguchi N, Minami T, Shirafuji N, Kanaoka Y, Tanaka T, Nagata A, et al.: Lack of tactile pain (allodynia) in lipocalin-type prostaglandin D synthase-deficient mice. Proc Natl Acad Sci USA 1999, 96:726-730.

79. Guo W, Wang H, Watanabe M, Shimizu K, Zou S, LaGraize SC, et al: Glial-cytokine-neuronal interactions underlying the mechanisms of persistent pain. J Neurosci 2007, 27:6006-60।8.

80. Moss A, Blackburn-Munro G, Garry EM, Blakemore JA, Dickinson T, Rosie $R$, et al: $A$ role of the ubiquitin-proteasome system in neuropathic pain. J Neurosci 2002, 22: I363-I372.

8I. Yamanaka H, Obata K, Kobayashi K, Dai Y, Fukuoka T, Noguchi K: Alteration of the cell adhesion molecule LI expression in a specific subset of primary afferent neurons contributes to neuropathic pain. Eur J Neurosci 2007, 25:1097-IIII.
Publish with Biomed Central and every scientist can read your work free of charge

"BioMed Central will be the most significant development for disseminating the results of biomedical research in our lifetime. "

Sir Paul Nurse, Cancer Research UK

Your research papers will be:

- available free of charge to the entire biomedical community

- peer reviewed and published immediately upon acceptance

- cited in PubMed and archived on PubMed Central

- yours - you keep the copyright
BioMedcentral 